\title{
Green Infrastructure for Sanitation in Settlements in the Global South: A Narrative Review of Socio-Technical Systems
}

\author{
Michaela F. Prescott ${ }^{\dagger}$, Meredith F. Dobbie ${ }^{*}+{ }^{\circledR}$ (D) and Diego Ramirez-Lovering \\ Monash Art Design and Architecture, Monash University, 900 Dandenong Road, \\ Caulfield East, VIC 3145, Australia; michaela.prescott@monash.edu (M.F.P.); diego.ramirez@monash.edu (D.R.-L.) \\ * Correspondence: meredith.dobbie@monash.edu \\ + Joint first authors.
}

Citation: Prescott, M.F.; Dobbie, M.F. Ramirez-Lovering, D. Green

Infrastructure for Sanitation in Settlements in the Global South: A Narrative Review of Socio-Technical Systems. Sustainability 2021, 13, 2071. https://doi.org/10.3390/su13042071

Academic Editor: Briony Rogers

Received: 14 January 2021

Accepted: 2 February 2021

Published: 15 February 2021

Publisher's Note: MDPI stays neutral with regard to jurisdictional claims in published maps and institutional affiliations.

Copyright: (C) 2021 by the authors. Licensee MDPI, Basel, Switzerland. This article is an open access article distributed under the terms and conditions of the Creative Commons Attribution (CC BY) license (https:/ / creativecommons.org/licenses/by/ $4.0 /)$.
Abstract: In the developing economies of the Global South, a fundamental challenge in the transition of settlements from rural or periurban to urban is increased environmental contamination as a result of poor sanitation and sanitation management. With governments' limited ability to connect all neighbourhoods to a city's existing municipal water, sewerage and other services, decentralised approaches using green infrastructure offer potential to address this challenge. In addition, green infrastructure might facilitate a move towards a holistic response to manage the full water cycle. This paper presents a narrative review of green infrastructure projects, involving constructed wetlands or their variants for wastewater treatment, within vulnerable communities in the Global South. It describes the scale and scope of each project, identifies the challenges of implementation, and reflects on their outcomes for different stakeholder groups. The review demonstrates that decentralised sanitation programs using constructed wetlands for wastewater treatment can provide a range of advantages/benefits/services, dependant on the specific sociocultural, political and biogeophysical contexts of each. Issues of governance and sociocultural appropriateness, rather than technical issues, challenged the implementation of green infrastructure for sanitation in these projects. Projects must be a collaboration between the government, nongovernment organisations and the community. Whether the project is organised from top-down or bottom-up, community consultation is essential. Context will determine the role of the community in the consultation process and the type of information required to guide the design, implementation and governance of the system. In every project to provide decentralised sanitation systems, the community must be participants, not simply beneficiaries.

Keywords: water sanitation and hygiene; WASH; sanitation; green infrastructure; water sensitive; wastewater treatment; Global South; decentralised; coproduction

\section{Introduction}

A goal of the United Nations (UN) Millennium Declaration was to halve the proportion of people without sustainable access to safe drinking water and basic sanitation by 2015. Although the target for drinking water was reached, that for sanitation was not [1]. Approximately 2.5 billion people still had no access to improved sanitation facilities, and almost 900 million were still practising open defaecation [2]. In cities in developing countries, most communities are served by nonnetworked, on-site sanitation systems, i.e., septic tanks, cesspits, or private or public pit latrines (unsewered ('dry') toilets) [3,4]. In 2002, on-site sanitation systems were the predominant form of disposal of most urban dwellers in Africa and Asia and many in Latin America, leading to contamination of water resources and risks to public health. Problems arise when there is a mismatch between septic tank density and the soil's capacity to assimilate the waste stream, resulting in soil and groundwater contamination, and when the septic tanks, cesspits and pit latrines are not emptied frequently enough or the collected waste is disposed of without treatment [4]. 
Even in cities with sewerage systems, only a small proportion of the wastewater within the system is collected and the remainder is discharged to open drains or disposed of locally [5]. In 2000, the World Health Organisation (WHO) estimated that only 35\% of wastewater collected by sewers is treated. The faecal sludge from these systems, often amounting to thousands of tonnes daily, is usually discharged untreated into the urban and periurban environment. The sludge might be used in agriculture or aquaculture or discharged directly into "lands, drainage ditches, onto urban spaces and into inland water, estuaries and the sea" [3] (p. 285). Consequently, water resources are contaminated-more than 880 million people rely on unclean drinking water [2] —and human health impacted. Diarrhoeal diseases kill 2.2 million people annually, including 1.6 million children under the age of five, and $10 \%$ of the population of developing countries have severe intestinal worm infections [2]. Diarrhoeal disease is the second leading cause of death in children globally [4].

The UN defines sanitation as "any safe excreta disposal that interrupts the transmission of faecal contaminants to humans" [2] (p. 649). Problems of adequate sanitation services are worsening in cities in developing countries as urban populations increase [1], and are exacerbated in informal settlements [6] and settlements in challenging environments, on marginal land or over water [7]. Sanitation coverage and levels of service are usually much lower than in formal settlements [8]. Urban planning and housing development in new areas for legal settlement in East Asia are beginning to include infrastructure considerations and, as a result, some areas are considered unsuitable for housing development because of public health risks or the high cost of providing infrastructure [7]. However, existing informal settlements might be legalised, which leads to pressure to provide sanitation, despite unsuitable locations and ground conditions, often with considerable social and technical challenges.

More attention has been given to the supply of affordable clean water than sanitation $[1,7]$. Once clean water is available, only then are communities interested in the provision of latrines and improved sanitation facilities. Certainly, many communities in settlements in developing countries do not understand the importance of safely managed sanitation for good health and disease prevention or the public health implications of open defaecation or fixed-point open defaecation $[4,7,9]$.

Sanitation services must extend beyond the simple provision of toilets to meet the UN Sustainable Development Goal 6 (SDG6) of ensuring the "availability and sustainable management of water and sanitation for all" [10]; the entire sanitation system must be provided, from pre-toilet to post-toilet [11]. Traditional centralised, big-pipe sewerage infrastructure cannot easily be implemented or expanded in many settlements in developing countries for economic, spatial, social, institutional, political and informational reasons [1]. Decentralised wastewater management systems offer an alternative solution, augmenting the capacity or function of existing traditional infrastructure [12] or operating independently to provide important treatment at-source [4]. They also facilitate greater community involvement in planning, implementation and management [5]. Water sensitive approaches through the use of green infrastructure (GI) are being explored as viable decentralised wastewater treatment options, particularly in developing countries [13]. Decentralised GI offers potential to provide sanitation services in settlements in urban, periurban or rural locations.

GI is formally defined as "an interconnected network of natural areas and other open spaces that conserves natural ecosystem values and functions, sustains clean air and water, and provides a wide array of benefits to people and wildlife" [14] (p. 1). This understanding has been expanded to include the use of nature-based systems as infrastructure. Given the environmental values of the location of many settlements in developing countries, GI offers "multifunctional, soft engineering alternatives to grey infrastructure, in low-income urban areas" ([6], p. 25). It also offers benefits of climate change adaptation and mitigation [6]. GI allows the integration of nature-based solutions for water into the built environment, in many cases highly modular constructed wetland systems [4]. These constructed wetlands 
are a low-cost technology that can provide rudimentary treatment in the management of wastewater. Different types of wetland are available, i.e., horizontal flow, vertical flow, subsurface flow and surface flow, depending on the context of the settlement. Once treated, the effluent can be used as a resource for horticultural and agricultural production, contributing to the local economy [4,9]. In such circumstances, GI as resource-oriented sanitation [15] offers the possibility of developing a circular economy [16] in which waste products are retained within the economy as resources with value.

GI also facilitates the monitoring and evaluation of the sanitation system to determine its sustainability, which is essential to achieve UN SDG6 [17,18]. Different sustainability indices have been developed for this purpose, varying in intent, focus, scale and detail. An early index [19] assesses performance of existing systems at a city scale, focusing on environmental issues and efficiency and performance of technical systems. The Water Sanitation and Hygiene (WASH) Performance Index evaluates a country's performance in water access and equity and sanitation access and equity using UN SDG indicators and data sources from the WHO/UN Joint Monitoring Program and trends in sustainability [20]. These two performance indices can guide future progress towards sustainability. In contrast, sanitation sustainability indices can use broader sets of descriptors or subindices to characterise existing or potential systems to be implemented in cities or local communities [17,18]. The Water and Sanitation Sustainability Index (WASSI) [17] is based on a five-dimensional sustainability concept related to place, permanence and persons, and uses nine descriptors and 15 indicators, including issues of governance and customer satisfaction. It is context-specific and uses local city-based data. Another sanitation sustainability index was developed to complement the WASH Performance Index by quantifying technical, social and economic aspects of a local community. Important in this index are the acceptability and public health indicators [18]. Such sanitation sustainability indices can guide decision-making in the selection, design and implementation of a sanitation system most suitable, and hence most likely to be sustainable, in a particular context.

As most studies of GI have been conducted in cities in Europe, North America, East Asia and Australia, its relevance and practical application in a wide range of contexts are not yet established [21]. There have been few studies of GI in informal settlements, with their challenges related to urban density, informality, and land tenure. This paper attempts to address this gap, with a review of projects in settlements in low and middle income countries (LMIC) in the Global South, in which GI was implemented to provide decentralised sanitation services. We were interested in the scale and scope of the GI intervention, the challenges of implementation, and the outcomes for different stakeholder groups, especially the advantages, benefits and/or services and, conversely, the disadvantages, costs and/or disservices of these programs for each group. The focus in many papers is on the technical aspects of subsurface constructed wetlands as wastewater treatment systems. This technology has great potential for treating wastewater in small and mediumsize communities because of its simplicity, reliable performance and ease of operation and maintenance [22]. The resultant effluent and byproducts can be used for irrigation, animal feed and fertiliser. In this paper, we are also interested in the social and cultural aspects associated with the implementation of these systems. As socio-technical systems, the benefits of the technology are dependent on adequate arrangements for operation and maintenance to ensure the long-term performance of the constructed wetlands, and community participation in educational programs promoting hygiene and environmental health [22]. Ultimately, we wish to establish the potential of decentralised GI for wastewater treatment in the Global South.

\section{Methods}

A systematic review was not undertaken for this paper, since these are best suited to narrowly defined questions involving quantitative data [23]. Despite its limitations, a narrative review format was adopted to best fulfil our intentions, allowing for a broader research question that would facilitate more comprehensive identification of issues within 
a given topic from a range of literature sources [23]. The review draws on published literature identified through a structured search process of Google Scholar, using terms related to sanitation provision, including: "green infrastructure", "nature-based systems", "constructed wetlands", "wetland", "wastewater treatment", "ecological sanitation design" and "Decentralised Wastewater Treatment Systems"(DEWATS). Searches were also conducted using the above terms in conjunction with "informal settlements". Given that we were interested in built, rather than conceptual, projects, grey literature was also considered, including reports by implementing agencies such as the WASH program and the WHO. Additional published literature was identified through the reference lists of key articles.

Publication date was not an excluding factor, and, although no geographic restrictions were included in the searches, the literature was reviewed for relevance to urban and periurban settings in LMIC. No language restrictions were placed on the search; however, only English language documents and abstracts were reviewed. As reflected in our search terms, we were most interested in the literature related to design and implementation of sanitation systems and literature relating to built projects only was included in the review. Natural GI systems that are providing wastewater treatment by convenience-rather than by design-as can occur within the unserviced informal settlement context $[6,24]$ were not considered.

Based on the LMIC filter, our search returned projects from countries within five of the six World Bank-identified regions: East Asia and the Pacific, Latin America and the Caribbean, the Middle East and North Africa, South Asia and Sub-Saharan Africa [25]. Finally, based on data availability and the inclusion criteria defined above, 13 projects were selected. These included projects from Indonesia, Costa Rica, Nicaragua, El Salvador, Peru, Colombia, Brazil, Uganda, Pakistan, Zimbabwe, the Philippines and Nepal.

We applied a classification based on Gauss (2008), which structured project reviews under the categories: "Design and construction", "Operation and maintenance" and "Community participation in implementation" [22]. These have been identified as important topics relating to the implementation of socio-technical systems, across literature on water, sanitation and hygiene.

\section{Results}

We selected for examination 13 projects in which constructed wetlands were used as GI to manage sanitation in settlements in the Global South. Descriptions of these projects differed, depending on the aim of the sanitation project and the aim of the authors in writing about it. Thus, in examining each project, direct comparisons may not be possible. Nevertheless, the critical aspects of the projects of interest in this study were the scale and scope of the intervention, and the challenges of implementation.

The scale and scope, with details of location, for each project are given in Table 1. This information was not always explicit in the description of the project and in some cases had to be inferred, indicated by a question mark. On this basis, seven projects were in periurban locations, two were rural, and four were urban. Location was not indicative of scale of operation, though. The urban constructed wetlands in Pereira, Colombia, catered for 280 people, whereas constructed wetlands in rural locations might cater for as few as four households in Santa Elena-Monteverde, Costa Rica, or as many as 5000 people in Nemanwa, Zimbabwe. Wetlands constructed in terrestrial periurban locations generally served upwards of 1000 people. In contrast, floating sanitation gardens in waterside villages in Indonesia were designed to serve two households. The preponderance of constructed wetlands in periurban locations could reflect the availability of space on the edge of cities rather than within them, for the provision of GI. 
Table 1. Selected projects using green infrastructure for wastewater treatment in settlements in the Global South.

\begin{tabular}{|c|c|c|c|c|c|c|}
\hline Project Name & Location & Rural/PeriUrban/Urban & $\begin{array}{l}\text { Year Completed } \\
\text { (Start-Up Date) }\end{array}$ & $\begin{array}{l}\text { Number of Houses/People } \\
\text { Serviced }\end{array}$ & Scope & Reference \\
\hline $\begin{array}{l}\text { BIOSANTER (Sanitation } \\
\text { management for waterside } \\
\text { villages) }\end{array}$ & $\begin{array}{l}\text { Village of Tanjung Pagar, } \\
\text { Banjarmasin, Indonesia }\end{array}$ & Periurban? & & 2 Households (8-14 people) & $\begin{array}{l}\text { - Floating toilet, biofilter tank and floating } \\
\text { sanitation gardens as secondary treatment. } \\
\text { Planted with water jasmine, productive crops, } \\
\text { rice; vegetable crops. }\end{array}$ & [26] \\
\hline Reedbed & $\begin{array}{l}\text { Santa Elena-Monteverde, } \\
\text { Costa Rica }\end{array}$ & Rural & 2001 & 4 Households & $\begin{array}{l}\text { - Reedbed system treating domestic greywater and } \\
\text { blackwater. } \\
\text { - Flows into pond and soakage area, surplus } \\
\text { treated water overflows to stream }\end{array}$ & [27] \\
\hline $\begin{array}{l}\text { Masaya pilot plant, } \\
\text { Reedbed 'Biofiltro' }\end{array}$ & Masaya, Nicaragua & Periurban & (1996) & 1000 people & $\begin{array}{l}\text { - Pretreatment with screen and grit tank; treatment } \\
\text { by Imhoff tank and } 4 \text { SSHF reedbeds. } \\
\text { Outflow used for horticulture; reedbed plants } \\
\text { used as fodder crop. }\end{array}$ & {$[22,28]$} \\
\hline \multirow[t]{2}{*}{ San José Las Flores } & $\begin{array}{l}\text { San José Las Flores, El } \\
\text { Salvador }\end{array}$ & Periurban? & $1997+(2000)$ & $\begin{array}{l}126+\text { Households }(650+ \\
\text { people) }\end{array}$ & $\begin{array}{l}\text { - Sewerage system used for most densely } \\
\text { populated part of village (126 households). } \\
\text { Wetland system and on-site sanitation (latrines) } \\
\text { used for rest of population. }\end{array}$ & {$[22,28]$} \\
\hline & Lima, Peru & Periurban & 2006 & 2500 people (three schemes) & $\begin{array}{l}\text { - Pretreatment with screen, grit separators and } \\
\text { sedimentation tanks. } \\
\text { - Constructed wetland of } 2 \text { SSHF reedbeds. }\end{array}$ & {$[22,28]$} \\
\hline \multirow[t]{3}{*}{$\begin{array}{l}\text { La Florida Wastewater } \\
\text { Treatment Plant }\end{array}$} & Pereira, Colombia & Urban & & 280 people & $\begin{array}{l}\text { - Primary and secondary treatment via existing } \\
\text { septic tank and anaerobic filter. } \\
\text { - } \quad \text { SSHF constructed wetlands as tertiary treatment. }\end{array}$ & {$[22,28]$} \\
\hline & Pasto, Colombia & Periurban & 2006 & 1000 people & $\begin{array}{l}\text { - } \quad \text { Constructed wetland providing secondary } \\
\text { treatment of effluent } \\
\text { - } \quad \text { Treated wastewater used for agriculture. }\end{array}$ & {$[22,29]$} \\
\hline & $\begin{array}{l}\text { Barrio of Jardim Petrolar } \\
\text { Alagoinhas, Brazil }\end{array}$ & Periurban & & 2500 people & $\begin{array}{l}\text { - Constructed wetland as treatment after grit } \\
\text { removal tank and anaerobic reactor. }\end{array}$ & [22] \\
\hline $\begin{array}{l}\text { Kisoro Town EcoSan pilot } \\
\text { project }\end{array}$ & Kisoro, Uganda & Urban & $1996-1999 / 2000$ & $\begin{array}{l}250+\text { house- } \\
\text { holds/institutions/public } \\
\text { facilities }\end{array}$ & $\begin{array}{l}\text { - Water-borne sanitation, sewer, constructed } \\
\text { wetland and reuse of outflow. } \\
\text { Combined with } 3 \text { other water-borne or dry } \\
\text { approaches dependent on location. }\end{array}$ & {$[30,31]$} \\
\hline Machaki village & Machaki village, Pakistan & Rural & $2006 ?$ & 49 Households (673 people) & $\begin{array}{l}\text { - Flush toilets and greywater connected to storage } \\
\text { tank and } 2 \text { SS constructed wetlands. } \\
\text { Outflow used by } 2 \text { local farmers who gave land } \\
\text { rights for system construction. }\end{array}$ & [8] \\
\hline
\end{tabular}


Table 1. Cont.

\begin{tabular}{|c|c|c|c|c|c|c|}
\hline Project Name & Location & Rural/PeriUrban/Urban & $\begin{array}{l}\text { Year Completed } \\
\text { (Start-Up Date) }\end{array}$ & $\begin{array}{c}\text { Number of Houses/People } \\
\text { Serviced }\end{array}$ & Scope & Reference \\
\hline & $\begin{array}{l}\text { Redcliff, Mupandawana } \\
\text { and Nemanwa, } \\
\text { Zimbabwe }\end{array}$ & Urban & 1999 & $\begin{array}{l}\text { Redcliff: } 40,000 \text { people; } \\
\text { Mupandawana: } 250 \\
\text { commercial }+270 \\
\text { residential properties (of } \\
\text { population, } 10,000 \text { ); } \\
\text { Nemanwa: } 5000 \text { people? }\end{array}$ & $\begin{array}{l}\text { Duckweed pond systems, constructed wetlands } \\
\text { and aquaculture. } \\
\text { - } \quad \text { Outflow reused for agriculture. } \\
\text { Mupandawa and Nemanwa: duckweed used in } \\
\text { chicken feed, raising broiler chickens for human } \\
\text { consumption. Project failed in Mupandawa. } \\
\text { Nemanwa: chicken droppings and dried } \\
\text { duckweed used in vegetable gardening project. }\end{array}$ & {$[28,32-34]$} \\
\hline GK Fisherman's village & Bayawan City, Philippines & Urban & & 715 Households & $\begin{array}{l}\text { Clustered septic tanks for solid removal and VF } \\
\text { and HF reedbeds }\left(\sim 2500 \mathrm{~m}^{2}\right) \text { for wastewater } \\
\text { treatment. } \\
\text { Wastewater used for construction and irrigating } \\
\text { public greens. } \\
\text { - Sludge from septic tanks treated in central } \\
\text { biodigester at sanitary landfill to generate biogas. }\end{array}$ & {$[35,36]$} \\
\hline Sunga Treatment System & $\begin{array}{l}\text { Thimi Municipality, } \\
\text { Kathmandu, Nepal }\end{array}$ & Periurban & 2005 & 80 Households & $\begin{array}{l}\text { - Pretreatment (coarse screen and grit chamber), } \\
\text { primary treatment in anaerobic baffled reactor, } \\
\text { hybrid constructed wetland (2 HFCWs and } 2 \\
\text { VFCWs), and sludge drying bed. } \\
\text { - Sludge used as fertiliser by farmers. }\end{array}$ & {$[37,38]$} \\
\hline
\end{tabular}

HF, horizontal flow; VF, vertical flow; SS, subsurface; $\mathrm{CW}$, constructed wetland. 
As we are interested in the implementation of GI in these projects as a socio-technical system, we focused on those aspects of the system where the technology could interact with the community and might be influenced by its social and cultural aspects. Hence, each project was analysed to reveal information about:

1. Operation and maintenance (O\&M)

- Who does it and how is it financed?

- How are the roles and responsibilities divided and what falls to communities?

2. Technical construction

- Availability of local experience and materials—new technologies/approaches.

- Opportunity for capacity building.

3. Sociocultural aspects

- Contextual adaptation—based on social norms, local cultural beliefs and practices.

- New technologies/approaches.

- Community participation (i.e., consultation, education, coproduction, codesign, comanagement).

The results are presented in Table 2.

The results are constrained by the information available in each project description. Nevertheless, for most we have been able to extract the relevant detail or infer it from the published material. The analysis of the results reveals that there were six approaches to the provision of GI for sanitation services in the 13 projects (Table 3). The BIOSANTER project in Indonesia is excluded from Table 3 as the data were insufficient to allocate it to a group. It was government-initiated but the extent of community involvement in consultation before the project was implemented and in management of the floating sanitation garden is unclear. In seven projects, the importance of community participation to implementation of the project was emphasised. These are highlighted in bold in Table 3. The purpose of community participation, though, differed between these seven projects, dependant on the sociocultural or biogeophysical context and needs of each. In Pakistan, Uganda and the Philippines, community participation informed the context-specific design and location of the toilets and associated infrastructure. In Alagohinas, Brazil, and Pasto, Colombia, it identified community sanitation and health priorities. In El Salvador and Nepal, it enabled the local community to operate and maintain the sanitation wastewater system, including the constructed wetlands. 
Table 2. Details of operation and maintenance (O\&M), technical construction and sociocultural aspects for projects in Global South.

\begin{tabular}{|c|c|c|c|c|c|c|c|c|}
\hline \multirow{2}{*}{$\begin{array}{l}\text { Project Name and } \\
\text { Location }\end{array}$} & \multicolumn{3}{|c|}{ O\&M } & \multicolumn{2}{|c|}{ Technical Construction } & \multicolumn{3}{|c|}{ Sociocultural Aspects } \\
\hline & Who Does It & How Financed & $\begin{array}{c}\text { Roles and } \\
\text { Responsibilities }\end{array}$ & $\begin{array}{l}\text { Local Experience and } \\
\text { Materials Available }\end{array}$ & $\begin{array}{c}\text { Opportunity for } \\
\text { Capacity Building }\end{array}$ & Contextual Adaptation & $\begin{array}{l}\text { New Technolo- } \\
\text { gies/Approaches }\end{array}$ & $\begin{array}{l}\text { Community } \\
\text { Participation }\end{array}$ \\
\hline $\begin{array}{l}\text { BIOSANTER (Sanitation } \\
\text { management for } \\
\text { waterside villages), } \\
\text { Indonesia }\end{array}$ & Property owner? & & & $\begin{array}{c}\text { Local materials used in } \\
\text { construction of toilet, } \\
\text { biofilter and sanitation } \\
\text { garden. Local aquatic } \\
\text { productive crop plants } \\
\text { used }\end{array}$ & Yes & $\begin{array}{l}\text { Apply established } \\
\text { technologies using locally } \\
\text { available materials, e.g., } \\
\text { plastic packaging, coir, } \\
\text { coconut fibre, wood } \\
\text { charcoal, plastic fishing } \\
\text { nets, local aquatic plants }\end{array}$ & $\begin{array}{l}\text { Innovative substitution } \\
\text { of biofilter components } \\
\text { with locally available } \\
\text { materials, often waste }\end{array}$ & Not specified \\
\hline Reedbed, Costa Rica & $\begin{array}{l}\text { Owner of land on which } \\
\text { reedbed is located }\end{array}$ & $\begin{array}{l}\text { Environmental services } \\
\text { contract between } \\
\text { households using } \\
\text { reedbed and land owner } \\
\text { of reedbed }\end{array}$ & $\begin{array}{l}\text { Responsibility for O\&M } \\
\text { falls to users and owner } \\
\text { of system }\end{array}$ & $\begin{array}{l}\text { Absence of natural } \\
\text { wetlands; Coix laryma-jobi } \\
\text { selected as emergent } \\
\text { macrophyte-naturalised } \\
\text { in Latin America, with } \\
\text { deep penetrating root } \\
\text { system }\end{array}$ & Yes & $\begin{array}{l}\text { Usual wetlands species } \\
\text { replaced with locally } \\
\text { available wild grass }\end{array}$ & $\begin{array}{l}\text { No natural wetlands due } \\
\text { to steep topography, new } \\
\text { technology low-cost } \\
\text { materials and locally } \\
\text { available plant species } \\
\text { present opportunity }\end{array}$ & Not specified \\
\hline $\begin{array}{l}\text { Masaya pilot plant, } \\
\text { Reedbed 'Biofiltro', } \\
\text { Nicaragua }\end{array}$ & $\begin{array}{l}\text { Well-trained local } \\
\text { operator }\end{array}$ & & & & $\begin{array}{c}\text { Success encouraged } \\
\text { adoption of technology } \\
\text { in other parts of Central } \\
\text { America }\end{array}$ & $\begin{array}{l}\text { Include local fodder crop } \\
\text { with high water and N } \\
\text { demand, in reedbed } \\
\text { planting. Recommended } \\
\text { that system be fenced off } \\
\text { to prevent theft and } \\
\text { unauthorised entry }\end{array}$ & & \\
\hline $\begin{array}{l}\text { San José Las Flores, El } \\
\text { Salvador }\end{array}$ & $\begin{array}{l}\text { Managed by local } \\
\text { committee, which } \\
\text { appointed local plant } \\
\text { operator, }\end{array}$ & $\begin{array}{l}\text { Financed by Swiss } \\
\text { Agency for Development } \\
\text { and Cooperation (SDC) } \\
\text { for first } 2 \text { years. Since } \\
\text { then, local plant operator } \\
\text { paid by tariffs collected } \\
\text { from community }\end{array}$ & $\begin{array}{l}\text { Assistance provided } \\
\text { initially to set up system, } \\
\text { then users operate and } \\
\text { manage it. System } \\
\text { adopted for simple O\&M } \\
\text { requirements, low } \\
\text { recurrent costs, stable } \\
\text { treatment process and } \\
\text { good treatment } \\
\text { performance }\end{array}$ & $\begin{array}{l}\text { Based on Masaya pilot } \\
\text { plant in Nicaragua. } \\
\text { System adopted because } \\
\text { of availability of } \\
\text { materials, stable } \\
\text { treatment. Local operator } \\
\text { trained at Masaya pilot } \\
\text { plant and has trained } \\
\text { others to fill role in his } \\
\text { absence }\end{array}$ & $\begin{array}{l}\text { Yes. Community } \\
\text { development included in } \\
\text { project, with financial } \\
\text { and technical support } \\
\text { from SDC and local NGO } \\
\text { Pro-Vida }\end{array}$ & $\begin{array}{l}\text { System copied from pilot } \\
\text { plant in Nicaragua }\end{array}$ & $\begin{array}{l}\text { Community elected } \\
\text { Municipal Water and } \\
\text { Environmental Sanitation } \\
\text { Committee. Multifaceted } \\
\text { project included } \\
\text { community development, } \\
\text { intensive hygiene } \\
\text { promotion, and } \\
\text { construction of sewerage } \\
\text { and wetland systems. } \\
\text { Hygiene promoters } \\
\text { trained by NGO raised } \\
\text { awareness of hygiene } \\
\text { and educated villagers }\end{array}$ & $\begin{array}{l}\text { Yes: “outstanding } \\
\text { example of community } \\
\text { participation in a } \\
\text { sanitation project and } \\
\text { community-based } \\
\text { management of the } \\
\text { sanitation system" [22] (p. } \\
\text { 31). Citizens highly } \\
\text { organised and motivated }\end{array}$ \\
\hline Lima, Peru & $\begin{array}{l}\text { SEDPAL (Lima's water } \\
\text { utility) }\end{array}$ & $\begin{array}{c}\text { SEDPAL annual O\&M } \\
\text { budget for infrastructure } \\
\text { maintenance }\end{array}$ & $\begin{array}{l}\text { No charge to users, } \\
\text { though separating } \\
\text { garbage and household } \\
\text { chemicals to facilitate } \\
\text { function of system }\end{array}$ & $\begin{array}{l}\text { Gravity-fed wetlands } \\
\text { constructed in cut sites in } \\
\text { steep sandy terrain. Local } \\
\text { emergent plant species, } \\
\text { Typha domingensis, used }\end{array}$ & Possibly & $\begin{array}{l}\text { Local species used in } \\
\text { reedbeds. Reedbeds are } \\
\text { multifunctional, treating } \\
\text { wastewater, providing } \\
\text { green space, and } \\
\text { operating as wind break } \\
\text { and mitigating erosion }\end{array}$ & $\begin{array}{l}\text { No natural wetlands due } \\
\text { to steep topography; new } \\
\text { technology and locally } \\
\text { available plant species } \\
\text { present opportunity }\end{array}$ & No \\
\hline
\end{tabular}


Table 2. Cont.

\begin{tabular}{|c|c|c|c|c|c|c|c|c|}
\hline \multirow[t]{2}{*}{$\begin{array}{l}\text { Project Name and } \\
\text { Location }\end{array}$} & \multicolumn{3}{|c|}{$\mathrm{O} \& \mathrm{M}$} & \multicolumn{2}{|c|}{ Technical Construction } & \multicolumn{3}{|c|}{ Sociocultural Aspects } \\
\hline & Who Does It & How Financed & $\begin{array}{c}\text { Roles and } \\
\text { Responsibilities }\end{array}$ & $\begin{array}{c}\text { Local Experience and } \\
\text { Materials Available }\end{array}$ & $\begin{array}{c}\text { Opportunity for } \\
\text { Capacity Building }\end{array}$ & Contextual Adaptation & $\begin{array}{l}\text { New Technolo- } \\
\text { gies/Approaches }\end{array}$ & $\begin{array}{l}\text { Community } \\
\text { Participation }\end{array}$ \\
\hline Pereira, Colombia & $\begin{array}{l}\text { Member of local } \\
\text { community }\end{array}$ & & & $\begin{array}{l}\text { Technical guidance and } \\
\text { monitoring by } \\
\text { Universidad Tecrica de } \\
\text { Pereira }\end{array}$ & $\begin{array}{l}\text { Use of different filter } \\
\text { media and local plants in } \\
\text { wetland }\end{array}$ & & & \\
\hline Pasto, Colombia & $\begin{array}{l}\text { Members of local } \\
\text { community }\end{array}$ & $\begin{array}{l}\text { Jointly by Pasto } \\
\text { municipality, local utility } \\
\text { (EMPASTO) and NGO } \\
\text { Semillero de Suenos }\end{array}$ & & & $\begin{array}{l}\text { Education to enable plant } \\
\text { management by } \\
\text { community members }\end{array}$ & & & $\begin{array}{l}\text { Extensive community } \\
\text { participation and } \\
\text { consultation to reveal } \\
\text { community priorities for } \\
\text { health and } \\
\text { environmental } \\
\text { protection, to promote } \\
\text { hygiene, and to provide } \\
\text { environmental education. } \\
\text { Aim to achieve } \\
\text { community ownership }\end{array}$ \\
\hline $\begin{array}{l}\text { Barrio of Jardim Petrolar } \\
\text { Alagoinhas, Brazil }\end{array}$ & $\begin{array}{l}\text { Servico Autonomo de } \\
\text { Agua e Esgoto de } \\
\text { Alagoinhas (SAAE, } \\
\text { municipal water and } \\
\text { sanitation utility) }\end{array}$ & SSAE & $\begin{array}{l}\text { Environmental sanitation } \\
\text { policy developed in } \\
\text { participatory process } \\
\text { with community, leading } \\
\text { to implementation of } \\
\text { project }\end{array}$ & & & $\begin{array}{l}\text { Drew on experience } \\
\text { acquired by Santa } \\
\text { Catarina's universities in } \\
\text { designing similar } \\
\text { systems }\end{array}$ & $\begin{array}{c}\text { Success of project } \\
\text { attributed to } \\
\text { participatory approach to } \\
\text { developing } \\
\text { environmental sanitation } \\
\text { policy [22] }\end{array}$ & $\begin{array}{l}\text { Municipality consulted } \\
\text { with various } \\
\text { stakeholders of } \\
\text { community in monthly } \\
\text { review meetings, to } \\
\text { develop environmental } \\
\text { sanitation policy }\end{array}$ \\
\hline $\begin{array}{l}\text { Kisoro Town EcoSan } \\
\text { pilot project, Uganda }\end{array}$ & User? & $\begin{array}{l}\text { Project initiated by } \\
\text { Austrian Development } \\
\text { Cooperation and } \\
\text { Ugandan Directorate of } \\
\text { Water Development }\end{array}$ & $\begin{array}{l}\text { User participation } \\
\text { important-focus of } \\
\text { feasibility study, with } \\
\text { local conditions }\end{array}$ & Not clear from study & $\begin{array}{l}\text { Yes. Community } \\
\text { engagement important to } \\
\text { provide knowledge to } \\
\text { ensure correct use of } \\
\text { toilets and develop sense } \\
\text { of ownership }\end{array}$ & $\begin{array}{l}\text { Four components suited } \\
\text { to local conditions: } \\
\text { reliance on pumped } \\
\text { groundwater, } \\
\text { hydrogeological } \\
\text { conditions of site (village } \\
\text { sits above water source), } \\
\text { poor sanitation coverage, } \\
\text { opportunity to reuse } \\
\text { byproducts in } \\
\text { horticulture and } \\
\text { agriculture. }\end{array}$ & $\begin{array}{l}\text { Mix of components to } \\
\text { adapt EcoSan system for } \\
\text { location } \\
\text { Decisions made on } \\
\text { scientific and, perhaps } \\
\text { more importantly, on } \\
\text { social and emotional } \\
\text { bases }\end{array}$ & $\begin{array}{c}\text { Community consultation } \\
\text { used drama, rallies and } \\
\text { meetings to reach most } \\
\text { community members. } \\
\text { Political leaders gave } \\
\text { commitment to project by } \\
\text { implementation } \\
\text { agreement }\end{array}$ \\
\hline Machaki village, Pakistan & $\begin{array}{l}\text { Government-run. Almost } \\
\text { no running and } \\
\text { maintenance costs. }\end{array}$ & $\begin{array}{l}\text { Government funded } 80 \% \\
=\text { materials } \\
\text { transportation, } \\
\text { construction and } \\
\text { supervision }\end{array}$ & $\begin{array}{l}\text { Pakistani convention is } \\
\text { for government to deliver } \\
\text { water services at minimal } \\
\text { or no cost. }\end{array}$ & $\begin{array}{l}\text { Villager contribution } 20 \% \\
=\text { all raw materials for } \\
\text { wetland construction and } \\
\text { local labour used }\end{array}$ & $\begin{array}{l}\text { Yes. Extensive } \\
\text { community consultation } \\
\text { to develop system } \\
\text { consistent with cultural } \\
\text { practices. This capacity } \\
\text { transferable. }\end{array}$ & $\begin{array}{l}\text { Adaptation of sanitation } \\
\text { system to local religious, } \\
\text { cultural and physical } \\
\text { requirements, e.g., water } \\
\text { flush. }\end{array}$ & $\begin{array}{l}\text { Ecological sanitation } \\
\text { system incorporating } \\
\text { water flush with } \\
\text { wastewater treatment by } \\
\text { constructed wetlands to } \\
\text { recover water and } \\
\text { nutrients, used by owner } \\
\text { of land occupied by } \\
\text { wetland }\end{array}$ & $\begin{array}{l}\text { Exhaustive and culturally } \\
\text { sensitive community } \\
\text { consultation and } \\
\text { codesign. Critical } \\
\text { involvement of religious } \\
\text { leaders }\end{array}$ \\
\hline
\end{tabular}


Table 2. Cont.

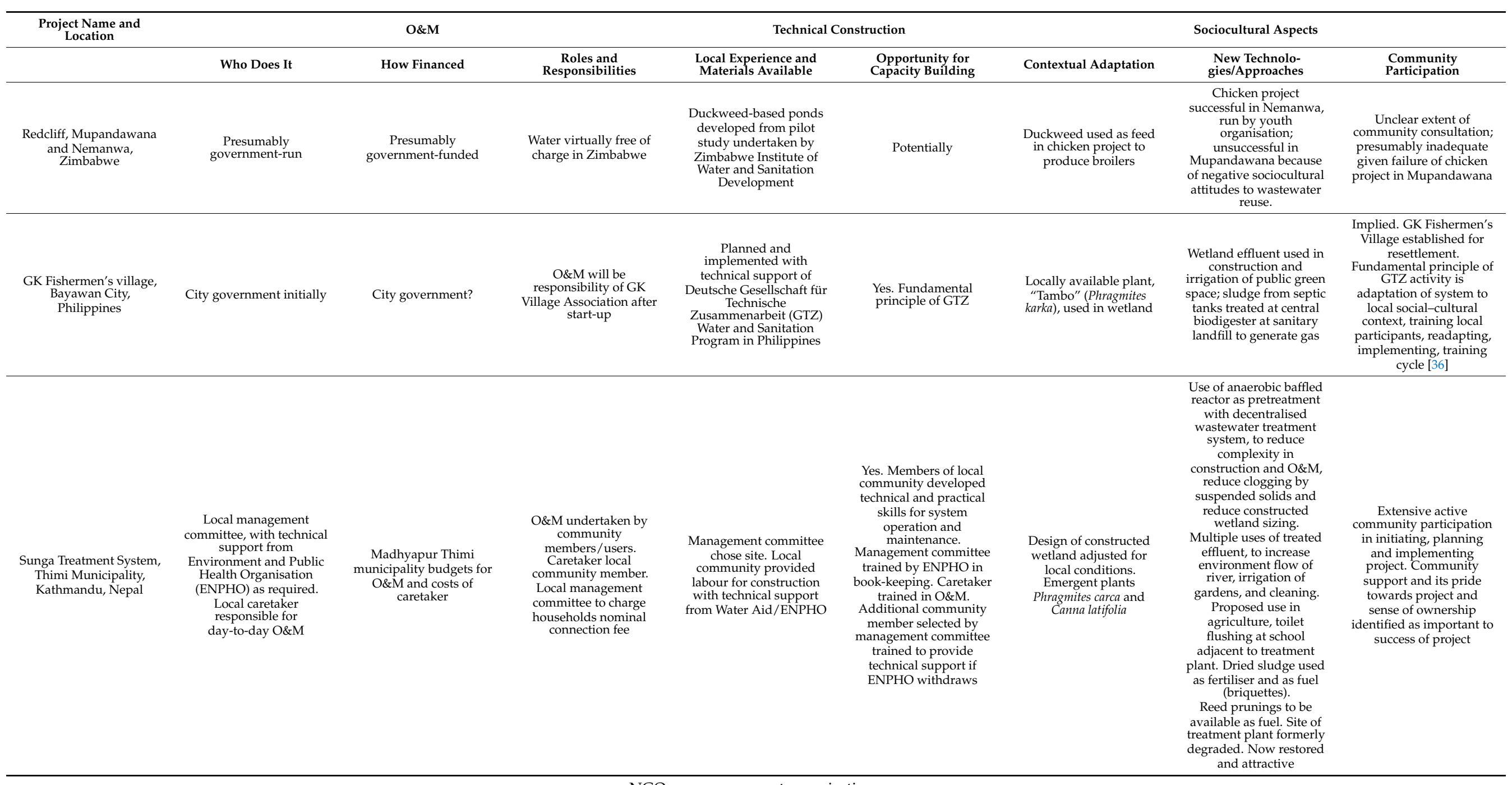


Table 3. Alternative approaches for provision of green infrastructure in projects. Projects in which community consultation was very important are given in bold.

\begin{tabular}{cccc}
\hline Initiation & Community Consultation & Management & Project \\
\hline University & No & Community & Pereira, Colombia; Nicaragua; Costa Rica \\
Government & No & Government & Lima, Peru; Zimbabwe \\
Government & Yes & Government & Brazil; Pakistan \\
Government + NGO & Yes & Probably community & Pasto, Colombia; Philippines \\
Government + NGO & Yes & Community & El Salvador \\
NGO & Yes & Community & Nepal \\
NGO + community & Yes & Community & \\
\hline
\end{tabular}

Design of context-specific infrastructure: Community participation in the Pakistan project was critical to an understanding of the sociocultural context of the project. In this case, sociocultural context included the community's perceptions of toilets and its cultural and religious practices and prohibitions related to defaecation, cleansing and cleanliness. This understanding was essential to ensure that the sanitation service for Machaki Village was designed to reflect its residents' values and practices and so would be used by them. Consequently, water-flushed toilets were adopted, rather than the usual dry toilets, and an underground sewerage system leading to constructed wetlands for treatment of wastewater, with water and nutrient reuse. This top-down system, in which the government provides water services, is the convention in Pakistan and an expectation. Nevertheless, in this project, the community did make an in-kind contribution to $20 \%$ of the cost. Similarly, community consultation in Kisoro, Uganda, also informed the design of the infrastructure, focused more on hydrogeological and other physical characteristics of the village rather than its residents' cultural and religious beliefs and values. The location of the village atop its only water source, soil structure and land scarcity determined the use of four sets of different components, some involving water-borne sanitation and others dry sanitation. Nevertheless, "social/emotional aspects" were considered as important, if not more so, as "rational processes" in decision-making [30] (p. 7). Effective community consultation was essential to reveal subjective responses to inform decision-making. So, too, in GK Fishermen's Village, Bayawan City, Philippines, the NGO behind the project, Deutsche Gesellschaft für Technische Zusammenarbeit, engaged in extensive community consultation to ensure that the infrastructure was best suited to the local sociocultural context. Community consultation was cyclic, involving the training of local participants, readapting, implementing, and retraining.

Identification of community sanitation and health priorities: In 2001, the Alagohinas municipality in Brazil developed a municipal environmental sanitation policy. A participatory process between local government, the local community and the local university then followed, to develop a municipal sanitation plan for Alagoinhas. Inevitably, community priorities for health and environmental protection would have been revealed. As a result, various sanitation projects, including constructed wetlands to treat wastewater in Alagoinhas, were implemented. Community participation in Pasto, Colombia, also revealed community priorities for health and environmental protection. This participation included consultation with community leaders, hygiene promotion and environment education. One of the priorities identified was for the community to take ownership of the sanitation project and to manage it, although the local water and sanitation utility is currently managing the system [22].

Management of sanitation wastewater system: In El Salvador and Nepal, community participation was geared towards enabling the local community to assume O\&M responsibilities for the project under a management committee. In both projects, the local community recognised the importance of sanitation and initiated the project, with support from NGOs. In El Salvador, the local community in San Jose Las Flores worked with the 
Swiss Agency for Development and Cooperation and the local NGO Pro-Vida to implement a project based on a pilot plant successfully constructed in Masaya, Nicaragua. It elected a Municipal Water and Environmental Sanitation Committee, which promoted the project. The project involved more than a sewerage system and constructed wetlands. It included on-site sanitation for residents outside the most densely populated part of the village, community development and intensive hygiene education. The committee manages the constructed wetland system, and appointed a plant operator from the community. This person was trained at the pilot plant in Masaya, and has trained members of the local committee and a member of a local youth group to ensure continuity of operation of the system in his absence. Users of the system pay a small fee. In Nepal, the NGO Environment and Public Health Organisation (ENPHO) had introduced decentralised wastewater technology to the country in 1997. The local Sunga community in Madhyapur Thimi municipality initiated the project to manage their wastewater. With WaterAid, ENPHO worked with a management committee selected by the community, comprising 17 members representing local leaders, community-based organisations, the community, the municipality and local schools. This committee chose the site for the constructed wetland and lobbied the municipality to acquire it. The community contributed labour for construction, with technical support from ENPHO. Then the management committee assumed responsibility for the system's operation and maintenance, with a caretaker, with funding derived from an annual contribution by the municipality and from nominal connection fees from users.

The distribution of the advantages, benefits and/or services and disadvantages, costs and/or disservices in each project are shown in Table 4. In general, in these projects, residents acquired advantages, benefits and services, with few disadvantages, costs and disservices, either collectively or individually. In each case, the residents obtained sanitation services supported by a constructed wetland, reedbed or floating sanitation garden. It can be assumed that their sanitation hygiene improved and so too their health. Certainly this would be expected in those projects in which hygiene practices were promoted through community engagement activities, e.g., El Salvador. The treated wastewater was used for irrigation in horticulture or agriculture, and solid byproducts used as fertiliser or fuel. In the Philippines, biogas was generated. The amenities of the local area were enhanced by the development of constructed wetlands, restoration of local landscapes, and the provision of green space. In Lima, Peru, wind erosion was mitigated. The environmental health of nearby waterways was improved, with better water quality and increased flow. Harvested biomass from the constructed wetlands or reedbeds was used as fodder. In several projects, individual residents, as a member of the management committee, plant operator or caretaker, developed management skills. Only in four projects did residents incur any financial cost for the operation and maintenance of the sanitation system. In most of these, a community committee of management assumed responsibility for the system and charged its users (the residents) a tariff or connection fee. In general, government or municipal funding met all costs. 


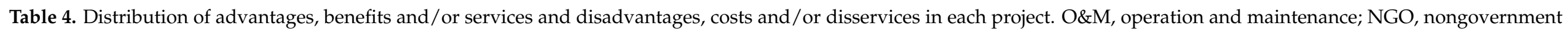
organisation.

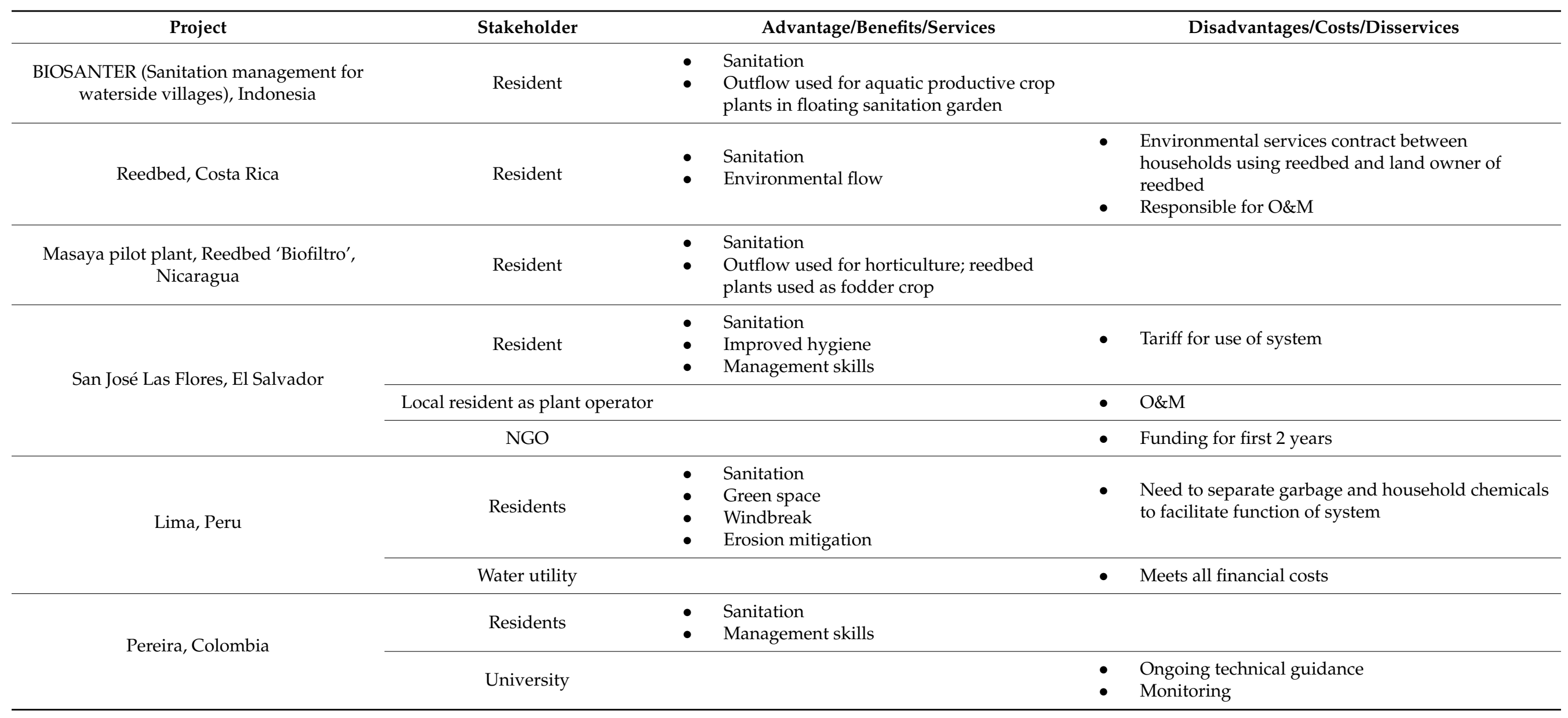


Table 4. Cont.

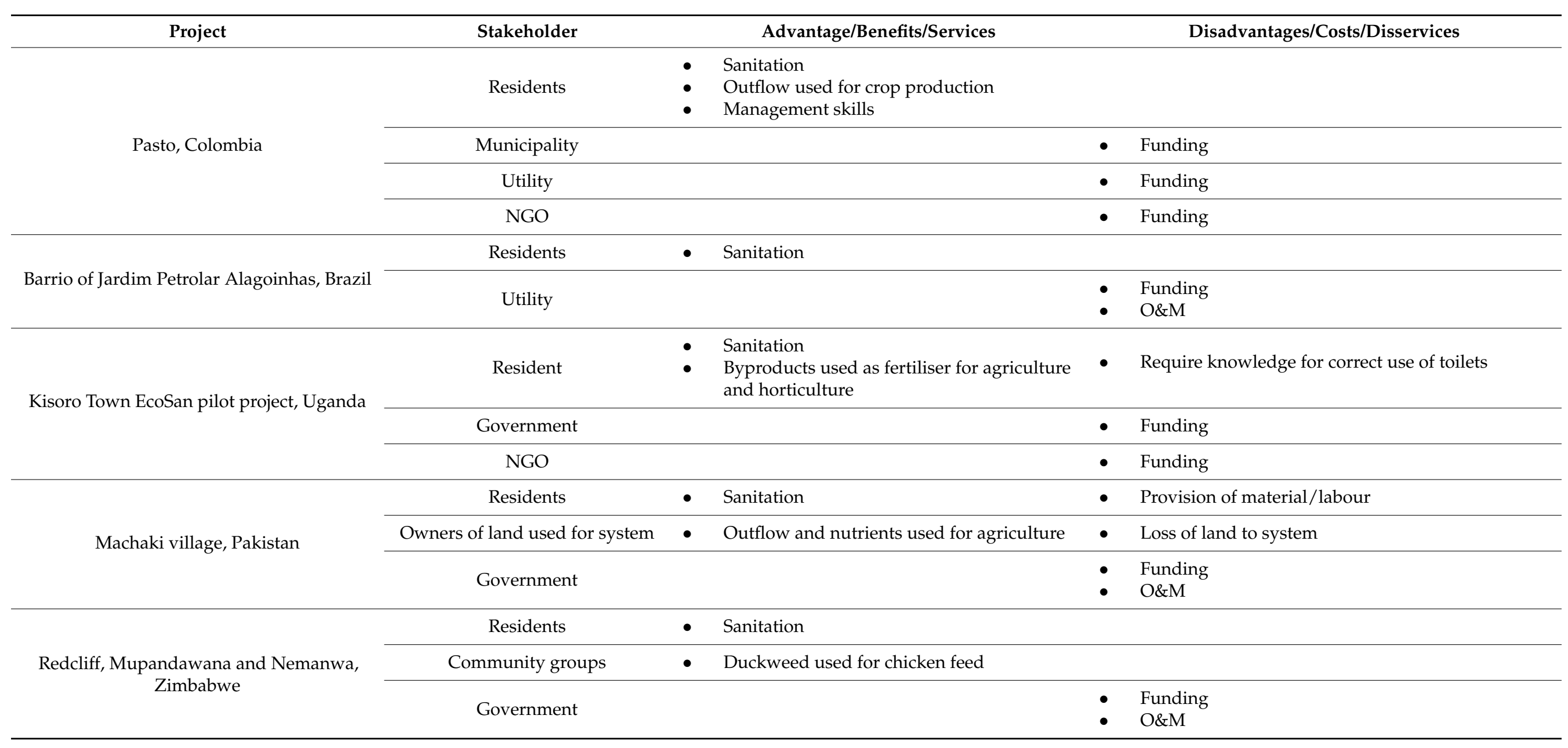


Table 4. Cont.

\begin{tabular}{|c|c|c|c|}
\hline Project & Stakeholder & Advantage/Benefits/Services & Disadvantages/Costs/Disservices \\
\hline \multirow{4}{*}{$\begin{array}{l}\text { GK Fishermen's village, Bayawan City, } \\
\text { Philippines }\end{array}$} & Residents & $\begin{array}{ll}\text { - } & \text { Sanitation } \\
\text { - } & \text { Biogas * }\end{array}$ & \\
\hline & Community & - Green space & \\
\hline & Government & & $\begin{array}{ll}- & \text { Funding } \\
- & \text { O\&M initially }\end{array}$ \\
\hline & Village association & & - $\quad$ O\&M once established \\
\hline \multirow[t]{7}{*}{$\begin{array}{l}\text { Sunga Treatment System, Thimi } \\
\text { Municipality, Kathmandu, Nepal }\end{array}$} & Residents & $\begin{array}{l}\text { - } \quad \text { Sanitation } \\
\text { Multiple uses of treated effluent, to increase } \\
\text { environment flow of river, irrigation of } \\
\text { gardens, and cleaning. Proposed use in } \\
\text { agriculture, toilet flushing at school adjacent } \\
\text { to treatment plant. } \\
\text { Dried sludge used as fertiliser and as fuel } \\
\text { (briquettes). } \\
\text { - } \quad \begin{array}{l}\text { Reed prunings to be available as fuel. } \\
\text { Site of treatment plant formerly degraded. }\end{array} \\
\text { Now restored and attractive }\end{array}$ & - $\quad$ Nominal fee \\
\hline & Local school & - $\quad$ Toilet flushing & \\
\hline & Community & - $\quad$ Restored landscape of treatment site & \\
\hline & Environment & - Increased river flow & \\
\hline & NGO & & - $\quad$ Technical support \\
\hline & Management committee & & - $\quad$ O\&M with support from NGO \\
\hline & Municipality & & - $\quad$ Funding \\
\hline
\end{tabular}

* It is unclear whether the biogas benefits the residents directly or is used elsewhere by the government. 


\section{Discussion and Concluding Remarks}

Decentralised sanitation as GI has been implemented effectively in the 13 projects in LMIC in the Global South examined in this review. Generalisations about the best way to provide sanitation are neither possible nor desirable as context is critical in each project. An important finding has been the contextual specificity of each project and the need for a context-specific sanitation solution for each. A form of GI-a vegetated treatment systemwas included in the mix of components to deliver a sanitation service, e.g., constructed wetland, floating sanitation garden or reedbed. Its exact design was determined by the political, sociocultural and biogeophysical contexts of the settlement and the availability of suitable materials and financial resources. In these socio-technical systems, the social aspect of each is as important as the technical aspect to ensure an effective system.

The uneven detail provided in each project limits their comparative analysis. However, the detail of two projects $[9,37,38]$ and inferences from the others reveal the importance of coproduction in the design and development of the sanitation systems, their construction, O\&M, and dissemination of complementary skills and knowledge, e.g., hygiene practices, to maximise the benefits of the systems. In some projects, delivery of the sanitation service was driven from the top-down, initiated, funded and implemented by the government, or by the government with support from an NGO. In other projects, it was initiated from the bottom-up, by the local community working with a level of government or an NGO. In yet another, it was initiated and implemented by a local community working with an NGO, with government funding for the construction of the system, which was then managed by the community. In each project, the specific political, biogeophysical, social and cultural contexts determined the mix of actors in the coproduction process. In all projects, however, the community was involved as active participants, not just as beneficiaries [39].

Writing about nature-based solutions for infrastructure in the Pacific, Zari (2019) emphasised that implementation demanded partnerships that embraced "community ownership, communal responsibility and creating consensus through dialogue" [39] (p. 8). Multistakeholder partnerships between governments, NGOs, and communities needed to align with customary practices. Such practices are components of a community's sociocultural context. Thus, sociocultural context is as important as biogeophysical context in establishing how the community will contribute to coproduction. This was evident in the Pakistani project [9]. The community expectation was that the government would supply sanitation and water services at minimal or no cost. Coproduction took the form of extensive input on social and religious beliefs, values, and practices involving water and defaecation, sewage and cleanliness. The community gained ownership through the design of a sanitation system specific to their precise needs. In addition, they contributed $20 \%$ of the cost through the supply of raw materials and labour in the construction of the treatment wetland. Consensus on the best system for the community was created by extensive consultation with the community, who sought guidance from their religious leaders. Finally, communal responsibility was established by a design that reflected the religious and sociocultural practices of the community. In contrast, coproduction in the Nepalese project $[37,38]$ was more comprehensive, with the community participating in every stage of the project. The community owned the project from the outset, initiating it with support from an NGO and local government. It is responsible for its operation and maintenance, again with support from local government. No doubt, the consensus required to achieve this was reached through extensive dialogue.

Both the Pakistan and Nepal projects demonstrate the value of communities working with government and nongovernment agencies to achieve sanitation services. Bottom-up approaches to GI without state involvement are often limited in available resources and short-lived because of the precarious living conditions of many residents in settlements in LMIC [40]. Residents have the motivation and social capacity to identify, prioritise, plan and implement projects to meet community needs, with or without government or NGO assistance, as demonstrated by the Nepal project, but they need government, NGOs or professionals to provide an enabling environment for the community-based approach to 
succeed [41,42]. On their own, self-help initiatives are coping strategies only [41]. Topdown approaches are constrained by a lack of adequate material and human resources, and various ecological, institutional, political and cultural challenges [1,43]. Governments might have insufficient resources, including financial resources, to implement a long-term strategy, necessary for development of infrastructure, or they might be ineffective in their social and regulatory roles [44]. Government policy might specifically limit the provision of sanitation infrastructure to interim solutions, such as periodic waste collection and chemical toilets (usually Ventilated Improved Pits) [42]. Such limitations might result from tensions between a responsibility to service what might be regarded as informal settlements, a need to discourage their growth, and a belief that they are temporary housing solutions until residents are relocated into housing projects or the settlements are upgraded to become "formalised" [8]. Lack of space or distance from bulk water infrastructure or wastewater treatment plants might prevent centralised, sewerage systems. Local soil and hydrological regimes, e.g., high watertable, might lead to ground or surface water pollution by dense onsite greywater dispersal systems $[1,4,8]$. Thus, hybrid approaches involving government, NGOs and communities working together are most likely to produce sustainable sanitation solutions, which are likely to rely on decentralised systems.

Challenges still remain, however, once the system is chosen and designed. Technical challenges exist in the construction of the system, often in isolated locations with possibly difficult access to the building materials and construction skills common in the Global North. In the projects explored here, many of the local communities, working with the government or an NGO, were innovative and focused on problem solving. Western building materials were often replaced with locally available materials. For example, in the BIOSANTER floating sanitation gardens in Indonesia, local materials were used in the construction of the toilet, biofilter and floating sanitation garden, including waste in the filter medium [26]. In Nepal, the design of the constructed wetland itself was altered to fit with local conditions $[37,38]$. In many projects, local aquatic plants were used in the constructed wetlands, reedbeds or floating sanitation gardens $[35,36]$ and in Costa Rica and Peru, where there were no natural wetlands, suitable local aquatic plants were chosen $[22,27,28]$. These aquatic plants were also productive crop plants in some projects, thereby contributing to the local community's economic base (e.g., [28,32-34]). Once the technical system was built, governance issues had to be resolved. For example, O\&M had to be arranged to ensure that the system functioned as intended and delivered the service satisfactorily. Funding for O\&M had to be obtained, and also the technical and managerial skills to undertake it. Tied up with O\&M are ethical issues and notions of equity [8]. Pan et al. (2015) explain that equity is "an 'ethical concept' related to notions of 'social justice, fairness and human rights', based on need as a foundation for the allocation of resources" [8] (p. 222). They add that this concept is value-laden and political, as is sustainability, and warn of a tension between meeting short-term goals and a long-term vision for sustainable and equitable sanitation services. Nevertheless, we regarded the projects here as ethical if O\&M was undertaken in a way that reflected the values and beliefs of the community and the community was consulted about management expectations [43]. Eales et al. (2013) advocate for a comanagement approach, distinguishing between above-ground and below-ground activities [45]. The former, which have direct benefits to communities, are day-to-day activities such as easily detectable minor repairs and are more appropriate for community-based management. The latter, which do not benefit communities directly, are more complex maintenance works—-such as desludging_-and are undertaken by local government or outsourced to private partners [45]. Sociocultural context is critical here. What is regarded as ethical in Pakistan might not be ethical in Nepal. Sociocultural context and the consequent community consultation also determined the appropriate contextual adaptation of the sanitation system in each project. It was not always effective, e.g., the chicken project in Mupandawana, Zimbabwe [28,32-34]. Duckweed was to be harvested from the wastewater treatment pond for reuse as chicken feed for broilers. The failure of the project was attributed to negative sociocultural attitudes to wastewater reuse. Appropriate 
community participation should have revealed such negative attitudes. Collaboration with the community must be productive to ensure "an inclusive and sustainable urban future" [40] (p. 79).

These challenges, and the ways in which they were addressed in each project, reinforce the importance of community participation in devising the sanitation project from the outset. Some of these projects are examples of "organised eclecticism" [43] (p. 15), in which there is a mix of technologies and strategies, at different scales, with different financial and governance arrangements, designed as fit-for-purpose, using both technical and socio-scientific knowledge, for the specific political, sociocultural and biogeophysical circumstances of a settlement. Oosterveer and Spaargaren (2010) describe this as a Modern Mixtures approach, which must be ecologically and institutionally sustainable, accessible, particularly for the poor, institutionally and technically feasible, resilient and robust [43]. It is not an inferior substitute, to be replaced in the future by a large-scale, highly technical centralised system but a modular approach that combines the most appropriate mix of technologies and governance options, best suited to the context. As this review has shown, selection of this mix relies on technical and sociocultural factors. Oosterveer and Spaargaren (2010) suggest that this selection should be augmented by environmental flow analysis [43].

The selection of the mix should also be informed by an understanding of the local economy and the contribution that byproducts of a sanitation system can make to establishment of a circular economy. Resource-oriented sanitation systems have the potential to generate an income for the community $[15,16,46]$. When the costs of an entire sanitation system, from pre-toilet to post-toilet, are calculated, including the use of treated urine and faeces as fertilizer or soil conditioner and the income from sale of agricultural, horticultural or other products derived from the system, resource-oriented sanitation systems are economically beneficial [11]. Critical to the success of this is the willingness of the local community to reuse the waste byproducts $[15,46]$. Traditional sociocultural practices in some countries, e.g., Korea, Japan and Vietnam, might support the use of harvested human waste for agricultural production [46]. In others, e.g., India, traditional uses of animal urine and manure provide a precedent for use of human waste, which was acceptable to about $50 \%$ of farmers in a study in Vellore. However, they preferred that their neighbours used the human waste as fertilizer and soil conditioner rather than their friends, family or colleagues [15]. Several projects in this review used treated wastewater to irrigate crops, with apparent success. The one failure involved the project in Mupandawana, Zimbabwe, in which duckweed harvested from the wastewater treatment pond was to be used as chicken feed. The potential of the sanitation system to create a resource, which could have contributed to the local economy, was lost, as was the opportunity to ensure the sustainability of the sanitation system [11]. This again highlights the importance of extensive and early consultation with all sanitation system stakeholders, including producers and consumers, in the system's conceptualization, design and implementation [15].

The advantages, benefits and services, and conversely the disadvantages, costs and disservices, were treated collectively in this paper, mostly because of the limited detail provided in the descriptions of each project. However, various ecosystem services have been related to GI [47] and can be expected to occur as a consequence of its implementation in the projects of this study. Before the various projects were initiated, the communities would already be deriving benefits from many ecosystem services in nearby natural and seminatural areas, including local landforms, vegetation, gardens, waterscapes and agricultural areas, by virtue of their location in "ecologically significant, environmentally sensitive and/or biodiversity-rich places within cities" [6](p. 24) or through their agricultural activity. Implementation of the sanitation projects using GI would inevitably deliver more ecosystem services [6]. Diep et al. (2019) warn that problems can arise if a primary objective of the GI is to protect ecologically fragile areas, when removal of residents might be necessary [21]. However, this was not reported in any of the projects in this review.

In several projects, the supplementation of water supply by effluent was an advantage/benefit/service from implementation of the decentralised wastewater treatment. 
Treated wastewater was used for environmental flows, crop irrigation and other purposes. To maximise the benefits of GI and increase the efficacy of WASH programs, CRC for Water Sensitive Cities (2017) argues that a holistic, integrated approach is essential. Acknowledging that delivering effective WASH programs is "necessarily different and more complex" [4] (p. 26) than in the Global North, they suggest that a combination of interventions that take into account context-specific social and biophysical factors at a range of scales should underpin funding policies. This aligns with the Modern Mixtures approach of Oosterveer and Spaargaren (2010), in which the entire water cycle can be managed [43]. Sinharoy et al. (2019) suggest that this might not be appropriate in all situations [1]. The provision of sanitation has lagged behind provision of water services worldwide, especially in urban areas. They suggest that it might be useful to consider them separately, "to tease out the separate challenges that have hampered the expansion of sanitation in dense urban environments" [1] (p. 6). The conclusion, of course, demonstrated by this narrative review, is that every community differs and the appropriate WASH service and its cobenefits must be unique, determined by political, biogeophysical and sociocultural contexts. A holistic approach might be the solution in one location but not another. Nevertheless, GI has great potential to contribute to WASH programs in the Global South. However, careful planning and comprehensive community participation with government and nongovernment entities are essential to determine the right socio-technical system for the right place.

More information is required to fully understand the success of the projects examined in this review, in particular relating to acceptance of the byproducts from the wastewater treatment for use, the methods of community consultation, and the hygiene education programs implemented for community members. In addition, it would be interesting to determine the sustainability of each system by applying a sustainable sanitation index, and to determine the contribution of the systems to establishing a circular economy for each community. These offer potential for further studies.

Author Contributions: Conceptualization, M.F.P., D.R.-L.; methodology, M.F.P., D.R.-L.; formal analysis, M.F.P., M.F.D.; writing—original draft preparation, M.F.P., M.F.D.; writing—review and editing, M.F.P., M.F.D., D.R.-L. All authors have read and agreed to the published version of the manuscript.

Funding: This research was funded by the Wellcome Trust 'Our Planet, Our Health', grant number 205222/Z/16/Z.

Institutional Review Board Statement: Ethical review and approval were waived for this study because data were accessed from published sources. There was no direct involvement of human participants in this study.

Informed Consent Statement: Not applicable.

Data Availability Statement: Data sharing not applicable.

Conflicts of Interest: The authors declare no conflict of interest.

\section{References}

1. Sinharoy, S.S.; Pittluck, R.; Clasen, T. Review of drivers and barriers of water and sanitation policies for urban informal settlements in low-income and middle-income countries. Util. Policy 2019, 60, 100957. [CrossRef]

2. Lai, K.M.; Ramirez, C.; Liu, W.; Kirilova, D.; Vick, D.; Mari, J.; Smith, R.; Lam, H.Y.; Ostovari, A.; Shibakawa, A.; et al. Bridging the sanitation gap between disaster relief and development. Disasters 2015, 39, 648-664. [CrossRef] [PubMed]

3. Ingallinella, A.M.; Sanguinetti, G.; Koottatep, T.; Montangero, A.; Strauss, M. The challenge of faecal sludge management in urban areas-strategies, regulations and treatment options. Water Sci. Technol. 2002, 46, 285-294. [CrossRef]

4. CRC for Water Sensitive Cities. Strengthening the Delivery of WASH in Urban Informal Settlements: Addressing Multiple Exposure Pathways in Urban Environments; Cooperative Research Centre for Water Sensitive Cities: Melbourne, Australia, 2018.

5. Heymans, C.; McCluney, F.; Parkinson, J. Driving policy change for decentralised wastewater management (DWWM). In Proceedings of the 30th WEDC International Conference, Vientiane, Laos, 25-29 October 2004; pp. 91-94.

6. Adegun, O.B. Green infrastructure in relation to informal urban settlements. J. Archit. Urban. 2017, 41, 22-33. [CrossRef]

7. Djonoputro, E.R.; Blackett, I.; Rosenboom, J.W.; Weitz, A. Understanding sanitation options in challenging environments. Waterlines 2010, 29, 186-203. [CrossRef] 
8. Pan, S.M.; Armitage, N.P.; Van Ryneveld, M.B. Sustainable and equitable sanitation in informal settlements in Cape Town: A common vision. Water $S A$ 2015, 41, 222-231. [CrossRef]

9. Nawab, B.; Nyborg, I.L.; Esser, K.B.; Jenssen, P.D. Cultural preferences in designing ecological sanitation systems in North West Frontier Province, Pakistan. J. Environ. Psychol. 2006, 26, 236-246. [CrossRef]

10. United Nations. Sustainable Development. Goal 6: Ensure Availability and Sustainable Management of Water and Sanitation for All. Available online: https:/ / sdgs.un.org/goals/goal6 (accessed on 31 January 2021).

11. Hashemi, S.; Boudaghpour, S. Economic analysis and probability of benefit of implementing onsite septic tank and resourceoriented sanitation systems in Seoul, South Korea. Environ. Technol. Innov. 2020, 18, 100762. [CrossRef]

12. Todeschini, S.; Papiri, S.; Ciaponi, C. Placement strategies and cumulative effects of wet-weather control practices for intermunicipal sewerage systems. Water Resour. Manag. 2018, 32, 2885-2900. [CrossRef]

13. Radin Mohamed, R.M.S.; Al-Gheethi, A.A.S.; Mohd Kassim, A.H. Management of Greywater in Developing Countries Alternative Practices, Treatment and Potential for Reuse and Recycling, 1st ed.; Water Science and Technology Library 87 Series; Springer International Publishing AG: Cham, Switzerland, 2019.

14. Benedict, M.A.; McMahon, E.T. Green Infrastructure: Linking Landscapes and Communities; Island Press: London, UK, 2006.

15. Simha, P.; Lalander, C.; Vinneras, B.; Ganesapillai, M. Farmer attitudes and perceptions to the re-use of fertiliser products from resource oriented sanitation systems-The case of Vellore, South India. Sci. Total Environ. 2017, 581-582, 885-896. [CrossRef]

16. Talluhela, A.C.; Ballard, H.H. Developing the circular economy in South Africa: Challenges and opportunities. In Sustainable Waste Management: Policies and Case Studies; Ghosh, S.K., Ed.; Springer Nature: Singapore, 2020; pp. 125-133.

17. Iribarnegaray, M.A.; D'Andrea, M.L.G.; Rodriguez-Alvarez, M.S.; Hernandez, M.E.; Brannstrom, C.; Seghezzo, L. From indicators to policies: Open sustainability assessment in the water and sanitation sector. Sustainability 2015, 7, 14537-14557. [CrossRef]

18. Hashemi, S. Sanitation sustainability index: A pilot approach to develop a community-based indicator for evaluating sustainability of sanitation systems. Sustainability 2020, 12, 6937. [CrossRef]

19. Lundin, M.; Molander, S.; Morrison, G.M. A set of indicators for the assessment of temporal variations in the sustainability of sanitary systems. Water Sci. Technol. 1999, 39, 235-242. [CrossRef]

20. Cronk, R.; Luh, J.; Meier, B.M.; Bartram, J. The WASH Performance Index. Available online: https:/ / waterinstitute.unc.edu/ wash-performance-index-report/ (accessed on 28 January 2021).

21. Diep, L.; Dodman, D.; Parikh, P. Green infrastructure in informal settlements through a Multi-Level Perspective. Water Altern. 2019, 12, 554-570.

22. Gauss, M. Constructed Wetlands: A Promising Wastewater Treatment System for Small Localities: Experiences from Latin America; Water and Sanitation Program (World Bank): Lima, Peru, 2008.

23. Collins, J.A.; Fauser, B.C.J.M. Balancing the strengths of systematic and narrative reviews. Hum. Reprod. Update 2005, 11, 103-104. [CrossRef]

24. Vollmer, D.; Gret-Regamey, A. Rivers as municipal infrastructure: Demand for environmental services in in-formal settlements along an Indonesian river. Glob. Environ. Chang. 2013, 23, 1542-1555. [CrossRef]

25. WHO. Definition of Regional Groupings. Available online: https://www.who.int/healthinfo/global_burden_disease/definition_ regions/en/ (accessed on 11 August 2020).

26. Sumidjan, I.Y. Floating sanitation in tidal area. J. Hum. Settl. 2015, 7, 46-56.

27. Dallas, S.; Scheffe, B.; Ho, G. Reedbeds for greywater treatment-Case study in Santa Elena-Monteverde, Costa Rica, Central America. Ecol. Eng. 2004, 23, 55-61. [CrossRef]

28. Chirisa, I.; Bandauko, E.; Matamanda, A.; Mandisvika, G. Decentralized domestic wastewater systems in developing countries: The case study of Harare (Zimbabwe). Appl. Water Sci. 2016, 7, 1069-1078. [CrossRef]

29. Castro Reis, M.; Magalhaes Orrico, S.R.; Mederios Martins, M.; Santos Moraes, L.R.; Silveira Bernades, R.; de Melo, G.B. O Emprego de 'Wetland' para o Tratamiento de Esgotos Domesticos. Available online: http:/ / www.semasa.sp.gov.br/Documentos/ ASSEMAE/Trab_110.pdf (accessed on 10 July 2020).

30. ADC. Ecological Sanitation: A Sustainable Approach to the Future; Austrian Development Cooperation: Vienna, Austria, 2004.

31. Langergraber, G.; Muellegger, E. Ecological Sanitation-A way to solve global sanitation problems? Environ. Int. 2005, 31, 433-444. [CrossRef] [PubMed]

32. Nhapi, I. The potential for the use of duckweed-based pond systems in Zimbabwe. Water SA 2004, 30, 115-120. [CrossRef]

33. Nhapi, I. A framework for the decentralised management of wastewater in Zimbabwe. Phys. Chem. Earth 2004, 29, 1265-1273. [CrossRef]

34. Nhapi, I. Options for Wastewater Management in Harare. Ph.D. Thesis, Wageningen University, Wageningen, The Netherlands, 2004.

35. Hollmer, R.J.; Miso, A.U. A city-wide Ecosan concept for Cagayan de Oro, Philippines. In Proceedings of the GTZ/BMZ/DWA Conference: "New Sanitation Concepts—International Project Experiences and Dissemination Strategies", Eschborn, Germany, 25-26 October 2006.

36. Batz, F.-J. (Ed.) Capacity Development in the Water Sector: How GTZ Supports Sustainable Water Management and Sanitation; International Water Policy Project; Deutsche Gesellschaft fur Technische Zusammenarbeit GTZ: Eschborn, Germany, 2007.

37. Rajbhandari, K. Sunga Constructed Wetland for Wastewater Management-A Case Study in Community Based Water Resource Management; WaterAid in Nepal: Kathmandu, Nepal, 2007. 
38. Singh, S.; Haberl, R.; Moog, O.; Shrestha, R.R.; Shrestha, P.; Shrestha, R. Performance of an anaerobic baffled reactor and hybrid constructed wetland treating high-strength wastewater in Nepal-a model for DEWATS. Ecol. Eng. 2009, 35, 654-660. [CrossRef]

39. Zari, M.P.; Kiddle, G.L.; Blaschke, P.; Gawler, S.; Loubser, D. Utilising nature-based solutions to increase resilience in Pacific Ocean cities. Ecosyst. Serv. 2019, 38, 1000968.

40. Adegun, O.B. Green Infrastructure in informal unplanned settlements: The case of Kyo Sands, Johannesburg. Int. J. Urban Sustain. Dev. 2019, 11, 68-80. [CrossRef]

41. Adegun, O.B. Coping with stormwater in a Johannesburg, South Africa, informal settlement. Proc. Inst. Civ. Eng. Munic. Eng. 2014, 167, 89-98. [CrossRef]

42. Adegun, O.B. State-led versus community-initiated: Stormwater drainage and informal settlement intervention in Johannesburg, South Africa. Environ. Urban. 2015, 27, 407-420. [CrossRef]

43. Oosterveer, P.; Spaargaren, G. Meeting social challenges in developing sustainable environmental infrastructures in east African cities. In Social Perspectives on the Sanitation Challenge; van Vliet, B., Oosterveer, P., Spaargaren, G., Eds.; Springer Science + Business Media: Dordrecht, The Netherlands, 2010; Chapter 2; pp. 11-30.

44. Amado, M.P.; Ramalhete, I.; Amado, A.; Freitas, J.C. Regeneration of informal areas: An integrated approach. Cities 2016, 58, 59-69. [CrossRef]

45. Eales, K.; Blackett, I.; Siregar, R.; Febriani, E. Review of Community-Managed Decentralized Wastewater Treatment Systems in Indonesia; International Bank for Reconstruction and Development/TheWorld Bank: Washington, DC, USA, 2013.

46. Hashemi, S.; Han, M. Field evaluation of the fertilizing potential of biologically treated sanitation products. Sci. Total Environ. 2019, 650, 1591-1598. [CrossRef]

47. Dobbie, M.F.; Brown, R.R. Cultural ecosystem services of wsud: What are they and why do they matter? In Proceedings of the 13th International Conference on Urban Drainage, Kuching, Malaysia, 7-12 September 2014. 